\title{
O2O Business Model of Meituan in China
}

\section{Md Saikat Hosen}

College of Management, Capital Normal University, Haidian District, Beijing, CHINA

Corresponding Contact:

Email: $4192928030 @$ cnu.edu.cn

Manuscript Received: 03 March 2020 - Revised: 28 May $2020 \quad$ - Accepted: 17 June 2020

\begin{abstract}
The research applies performance evaluation of $\mathrm{O} 2 \mathrm{O}$ Business Model of China. It means evaluate how well the company performance. The focus aim is achieved through the O2O Business Model and Meituan, Ratio analysis of Meituan (20172019), share price movement we have use average moving Meituan Dianping (3690.HK), price to sales ratio among E-commerce firms. It is most important factor for performance evaluation. The graphical analysis and comparison are applying analysis and company's measurement of all type of financial ratio. Share price movement indicate the trend of company's present performance, as well as price to sales ration comparison among other tech companies. That Meituan is waiting, the company will grow strongly by its core market the food delivery business.
\end{abstract}

Key Words: Business Model, E-Commerce, Meituan, China, Financial Ratio

\section{INTRODUCTION}

$\mathrm{O} 2 \mathrm{O}$ (Online to Offline) Business model of Meituan evaluation of a company is usually related to how well a company do distribution, customer satisfaction, revenue, expenses, share price movement and the core business of food delivery business. In order to determine the distribution of the E-commerce company and to make a judgment of how well the $\mathrm{O} 2 \mathrm{O}$ business model customer satisfaction. Its operation and management and how well the company has been able to utilize its revenue and expenses. I have used ratio analysis for easily measurement of activity position, liquidity position, profitability and leverage for the performance evaluation. It analysis the company use of its assets and control of its expenses. I have used share price movement for easily measurement of daily, weekly and monthly share price moving trade. As well as I used the E-commerce industry price-to-sales ratio that compare between other tech companies. O2O refers to companies with an online store as well as physical retail locations. Consumers can choose and buy, pay online, and then go offline store. The $\mathrm{O} 2 \mathrm{O}$ has formed stable development pattern, and the $\mathrm{O} 2 \mathrm{O}$ development in China is now stable and matured. Meituan and Alibaba group holding limited network is one the firster O2O website in mainland China, the Meituan launched 2010 March 4 by the founder Wang Xing. 


\section{Scope of the Research}

In master program is building up to the theoretical and practical knowledge about business administration which is help us the corporate knowledge. The course E-commerce research is an attempt to provide business students an orientation to a real-life business situation in which we can observe and evaluate the use and applicability of the theoretical concepts, which were taught in the classroom. As a student of e-commerce course, I preferred to complete my research in E-commerce Sector like $\mathrm{O} 2 \mathrm{O}$ business model. Then I got a chance to complete the research of tech company Meituan in China.

\section{Research Questions}

- What is the performance of the company related to distribution and customer satisfaction?

- What is the performance of the company related to activity position?

- What is the performance of the company related to liquidity position?

- What is the performance of the company related to profitability position?

- What is the performance of the company related to debt management position?

- What is the performance of share price movement?

- What is the performance among other companies' price to sales position?

\section{Objective of the research}

General Objective of this study is to analysis O2O Business Model of Meituan in China. The specific objectives are to give a brief overview on Meituan-Dianping (美团网), to assess how distribution with customer satisfaction, to evaluate Activity, Liquidity, Profitability, Leverage, to do analysis of moving average, and to do assess price to sales ratio among ecommerce firms.

\section{Data Sources}

This research was conducted mainly based on secondary information, annual report of Meituan-Dianping (美团网) from 2017-2019, brochures of O2O business model, different written document of Meituan-Dianping (美团网), newspapers, websites, and journals.

\section{LITERATURE REVIEW}

In China combination between e-commerce and industrial internet very popular resent year. Internet finance, like Ctrip ( $\mathrm{Lu} \& \mathrm{Liu}, 2016)$. An initial understanding of consumer behavior in $\mathrm{O} 2 \mathrm{O}$ commerce context and contributes to trust transfer theory and commitment. In long term is harmful to $\mathrm{O} 2 \mathrm{O}$ platform because consumers can easily switch among platforms online, trust theory can be transferred between entities associated with each other (Xiao, et al., 2017). The impact of fairness on ordering decision and coordination in a dual- channel supply chain system consisting of one manufacturer and one retailer under the $\mathrm{O} 2 \mathrm{O}$ model (Yu et al., 2019). As the effective integration of real economy and virtual economy and virtual economy, the $\mathrm{O} 2 \mathrm{O}$ model has a broader development space in the fourth communications era, based on the wechat platform technology (Aiying, et al., 2015). Customer become loyal and behave loyally because of psychological change processes. Emotion and cognition are critical phyhological states that influence consumer, and they are key elements of the consumption experience (Hsich, 2017). Online shopping model could integrate the online service experience properly, meals delivery websites and application App platform for mobile phone (Xu et al., 2018). 
The shopper visits the store's website frequently using a private profile. Mobile commerce allows the shopper to perform many of the activities as online commerce using a smartphone or tablet instead of a desktop computer (Moon \& Armstong, 2019). Time risk- consuming waste caused by the need to adjust, repair or refund the purchased product. Functional riskthe product does not have the risk that people expect the performance on product performance is worse that the competitor's product. Psychological risk- the risk of harming the customer's self-emotion due to mistake in the purchase decision (Tong \& Zhun, 2019). The demand volume is enormous and is increasing quickly. The first attempt to propose an optimization model for determining the optimal capacity for mixed work force, viz in-house, full time crowdsourced, and part time crowd sourced drivers (Dai \& Liu, 2019). Korean O2O platforms is yanolja, one of rental accommodation services in Korea. This firm has succeeded in matching joint services. Accommodation + activities= product combination $(H o \&$ Kitchen, 2020).

O2O business model of Meituan in China, we focus on the operational style- Meituan has offline many client shop, very well reputed supper App, as well as faster AI system. Discussion, firstly qualitative- supper App, AI system, offline operation. Secondly quantitative- Financial ratio analysis used 3 years' data, moving average- 100 days and compare between tech companies price to sales ratio. We have discussion about $\mathrm{O} 2 \mathrm{O}$ model with China and introduce to Meituan is upcoming tech giant in China as well as top E commerce company.

\section{OVERVIEW OF MEITUAN-Dianping (美团网)}

In Chinese "Mei" means Beautiful and "Tuan" means together. Meituan Dianping is china's leading e-commerce platform for services. It's a platform that uses technology to connect consumers and merchants meet people's daily needs for food and event extend to broaden lifestyle and travel services (Kosinus, 2019). The mission of Meituan is "We help people eat better, live better". As China's leading e-commerce platform for services, Meituan operates well-known mobile apps in China, including Meituan, Dianping, Meituan Waimai, Mobike and others. Meituan offers over 200 service categories including catering, on-demand delivery, car-hailing, bike-sharing, hotel and travel booking, movie ticketing, and other entertainment and lifestyle services, and covers 2800 cities and countries across China.

The total transaction amount of Meituan reached RMB 515.6 billion in 2018, with an increase of $44.3 \%$ over the same period of last year. The total annual numbers of transaction users and active online merchants of Meituan reached 400 million and 5.8 million in 2018, respectively. Meituan Dianping (stock code: 3690 .HK) was officially listed on the Main Board of the Stock Exchange of Hong Kong Limited (HKEX) on September 20, 2018 (Dianping, 2018).

\section{Characteristics of O2O Business Model}

The $\mathrm{O} 2 \mathrm{O}$ concept introduced in china for the very first time in November 2011. O2O business run into U.S by Yelp, in Australia- productreviw.com, in Hong Kong openrice.com, and Main land China Meitual-Dianping. $\mathrm{O} 2 \mathrm{O}$ is an e-commerce platform that provides us with a one stop business solution. It acts as business partner and consultant. Online-to-offline commerce, or $\mathrm{O} 2 \mathrm{O}$, is a business model that searches customer online and brings them between the real worlds to make purchases in physical stores. One aspect of the newer $\mathrm{O} 2 \mathrm{O}$ initiatives is the ability to pay online and then receive a product in an offline business entity.

In August 2010, the concept of O2O is introduced by Alex Rampell when he analyzed Groupon, Open Table, Restaurant and SpaFinder, Alex Rampell discovers that their common 
points are as follow: they are all promote online business to offline business (Wan et al., 2016). The business model $\mathrm{O} 2 \mathrm{O}$ arises with the combination into online virtual world and offline real world in the technology age. O2O refers to companies with an online store as well as offline business entity. Consumers can choose and buy, pay online, and then go physical store.

\section{Combination With O2O Model and Meituan}

In China the Meituan- $\mathrm{O} 2 \mathrm{O}$ business model is a fast-growing and stable business. The Meituan- $\mathrm{O} 2 \mathrm{O}$ business model based on 6 major frameworks as follows: Customer, telecom operator, supper app, offline business entity, payment platform, delivery.

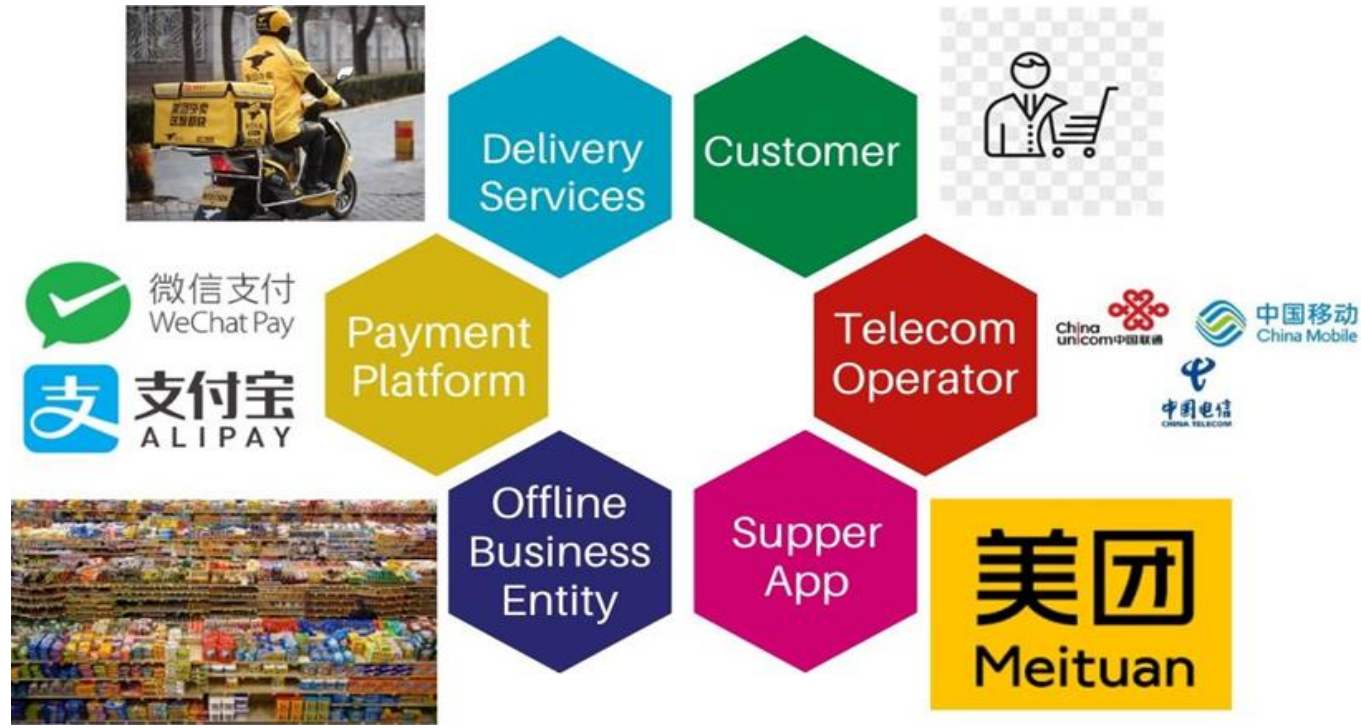

Graph 1: Combination with $\mathrm{O} 2 \mathrm{O}$ and Meituan

- Customer: The more people in China go in cash less, they will use more these online services. We use our phone most of the instead of a browser it just saves time for the consumer, the company which is providing service has more engagement and users are remaining longer inside the app (The investment ABC., 2020, March 05).

- Telecom Operator: China's three major mobile operators- China Mobile, China Unicom and China Telecom launched their 5G service in China. Subscribers have been using able to enjoy connection way faster than $4 \mathrm{G}$ and less expensive. $5 \mathrm{G}$ technology have provide key infrastructure for the development of China's digital economy and bring great convenience to people's life.

- $\quad$ Super App: Meituan-Dianping with a super app for kinds of services. Meituan-Dianping is not a slam start-up as we never might think only because we have never heard of it. It currently has roughly 450 million users on its platform and fast growing.

- Offline Business entity: Mr. Liu a small business owner, he can use the app in a different way confirming an early morning delivery and taking inventory at his restaurant. Now he can host his e-menu and add today's special before any customer arrive. Lunch time is rush hour for Meituan offline business owner. Ms. Luag have order for an office lunch, her order is sent to Mr. Liu where he accepts and gets started cooking the meal. 
- Payment platform: In China mainly we have two payment platforms one is Alipay another one is WeChat pay. When we open bank account basically we can link that bank account to Alipay and WeChat pay. Alipay and WeChat is amazing it's like a one and all app, we can use chatting services, as translator, and payment platform.

- Delivery services: Delivery is a major aspect of Meituan-Dianping services. Mr. Zang wu is a delivery driver. Meituan A.I powered intelligent dispatch system pre-selects the most suitable delivery rider to each customer ensuring the food is delivered in the shorts time possible.

\section{Distribution Services With Customer Satisfaction}

There are tens of millions of these orders placed and completed through Meituan delivery every single day. Meituan's AI powered intelligent dispatch system can determine the optimum delivery route within millisecond. Meituan-Dianping is exploring new horizons with AI driving technology and cloud hub, then can accurately navigation between city scopes to deliver meals.

Now let's see how Meituan-Dianping can bring us the local experience in a new city with Feng and Mao at they plan a trip to Shanghai for Feng's birthday. First things first, Mao books their flight through Meituan app. He can use the app to browse and pick out a high rated fivestar hotel for their stay as well. Feng and Mao check into their hotel with a deposit paid through the hotel booking feature. The drop their luggage off in the room which they find is even more spacious than in the photographs. Mao can book their tickets to Disney and then hire a cab to take them there too all through Meituan's different features on the phone. With everything set up and ready to go they are off to enjoy the magic kingdom. In the car ride back the app suggests a black pearl rated restaurant for dinner one of dingping's highest rated establishment an ultimate list of quality restaurants- each selected from a unique Chinese perspective. Mao can even use the app to put in on order, so the meal will be ready a soon as they arrive. Mao opens the Meituan app and the next destination is already suggested "Karaoke"- He finds a local deal and books their room at a discount the couple arrives and Mao shows the receipt to open their room. Then they call some friends Mao orders a last minute birthday gift to be delivered to the Karaoke- adding the perfect touch to the birthday girl's big bash (Kosinus, 2019).

\section{RATIO ANALYSIS}

Ratio analysis is a quantitative method of gaining insight into a company's activity, liquidity, operational efficiency, and profitability by studying its financial statements such as the balance sheet and income statement. Ratio analysis is a cornerstone of fundamental equity analysis.

\section{Activity ratio}

The activity ratio analysis is being applied for the measurement of the company's working capital, fixed asset, and total asset usages efficiency.

Working asset turnover: Working capital is the money available to fund a company's day to day operations.

Working capital turnover $=$ Sales $/$ Working Capital (times)

\begin{tabular}{|c|c|c|c|c|}
\hline Year & 2019 & 2018 & 2017 & Average \\
\hline Meituan & 2.141 & 1.578 & 1.000 & 1.573 \\
\hline
\end{tabular}




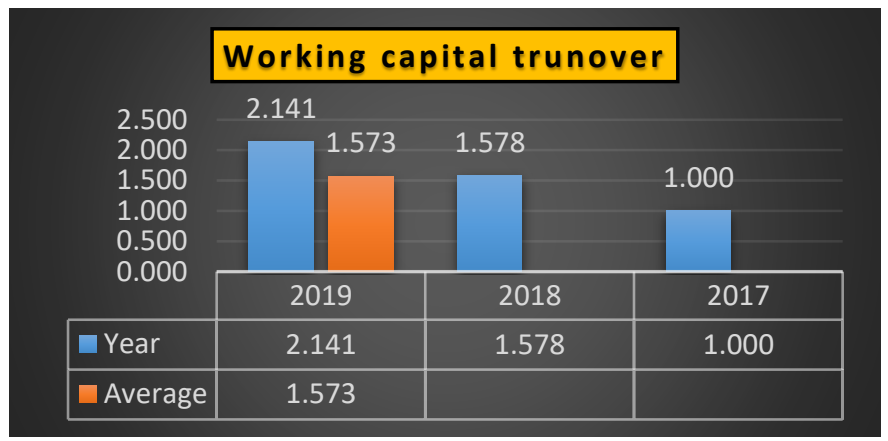

Comments: According to the findings of Working capital turnover ratio shows that, 2019 were better performing in the year. Where year average is 1.573 times and 2019 is 2.141 times, that means Working capital amount of operating capital needed to maintain a given level of sales over year 2.141 times.

Fixed asset turnover (FAT): It determines the effectiveness in generating net sales revenue from investments in net property, plant, and equipment back into the company evaluates only the investments. Fixed asset turnover ratio=Sales/fixed assets (times).

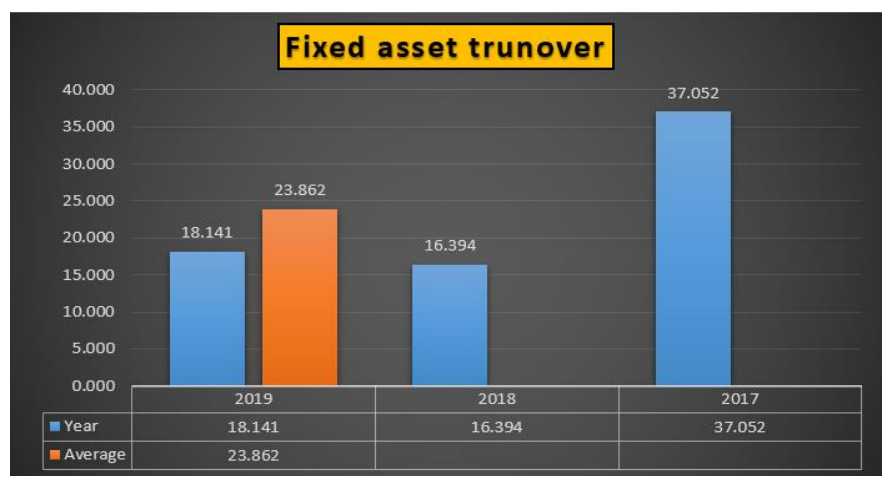

Comments: According to the findings of fixed asset turnover ratio shows that, 2018 Ware is better performing in the year. Where year average is 23.862 times and 2018 is 16.394 times, that means fixed asset turnover ratios measure the efficiency investment to generate sales a given level of sales over year 16.394 times.

Total asset turnover (TAT): Total asset turnover is a financial ratio that measures the efficiency of a company's use of its assets in generating sales revenue or sales income to the company. Total assets Turnover=Sales/Total assets (times).

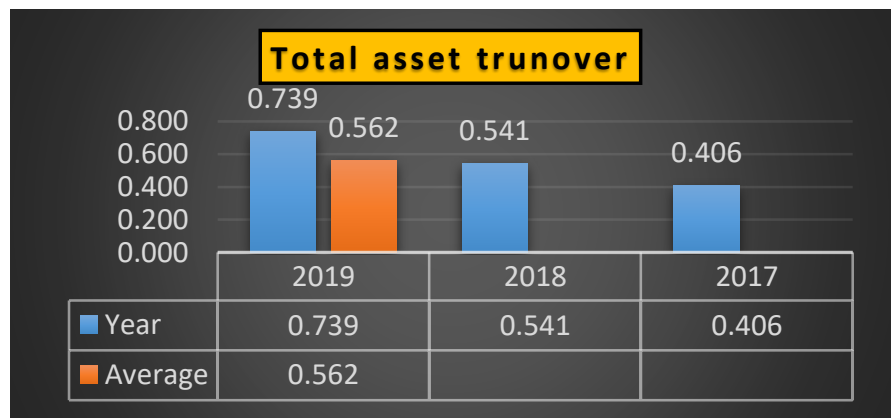


Comments: According to the findings of total assets turnover ratio shows that 2019 are is better performing in the year. Where year average is 0.562 times and 2019 is 0.739 times, that means total assets turnover indicates the efficiency with which the firm uses its assets to generate sales a given level of sales over year 0.739 times.

\section{Liquidity ratio}

Liquidity ratios are a class of financial metrics used to determine a debtor's ability to pay off current debt obligations without raising external capital. Liquidity ratios are measure the ability of a company to measure its current ratio, quick ratio, cash ratio obligations.

Current ratio (CR): The current ratio is a liquidity ratio that measures a company's ability to pay short-term obligations or those due within one year.

\section{Current Ratio $=$ Current assets/current Liabilities.}

\begin{tabular}{|c|c|c|c|c|}
\hline Year & 2019 & 2018 & 2017 & Average \\
\hline Meituan & 2.245 & 2.298 & 2.653 & 2.399 \\
\hline
\end{tabular}

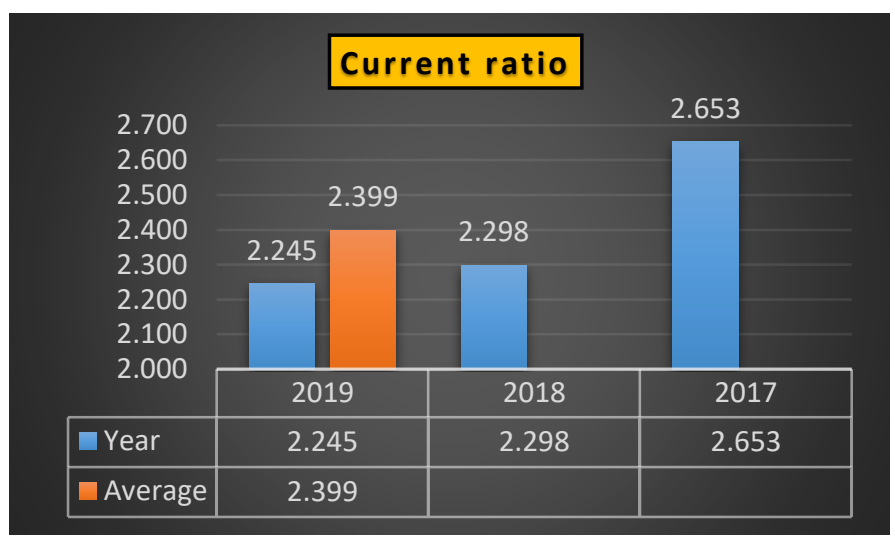

Comments: According to the findings of Current Ratio shows that, 2017 ware is better performing in the year where year average is 2.399 and 2017 is 2.653 that means the firm's ability to meet its short term obligation over year 2.653 .

Quick ratio (QR): The quick ratio or acid test is a calculation that measures a company's ability to meet its short-term obligations with its most liquid assets within three months. Quick Ratio= (current assets - inventories) /current liabilities.

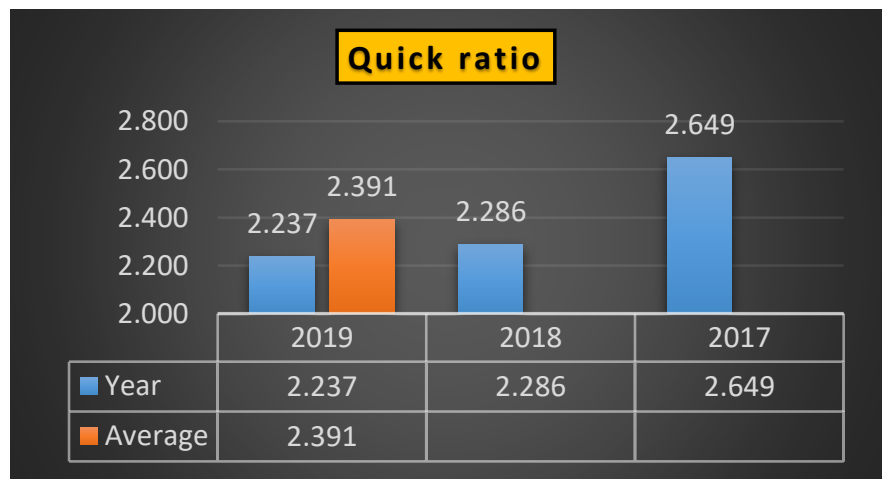


Comments: According to the findings of Quick Ratio shows that, 2019 were is better performing in the year. Where year average is 2.391 and 2019 is 2.237 . It actually measure the immediate short-term debt paying ability over year 2.237.

Cash ratio (CR): The cash ratio is a measurement of a company's liquidity, specifically the ratio of a company's total cash and cash equivalents to its current liabilities.

Cash Ratio=cash + mar. Sec/current liabilities

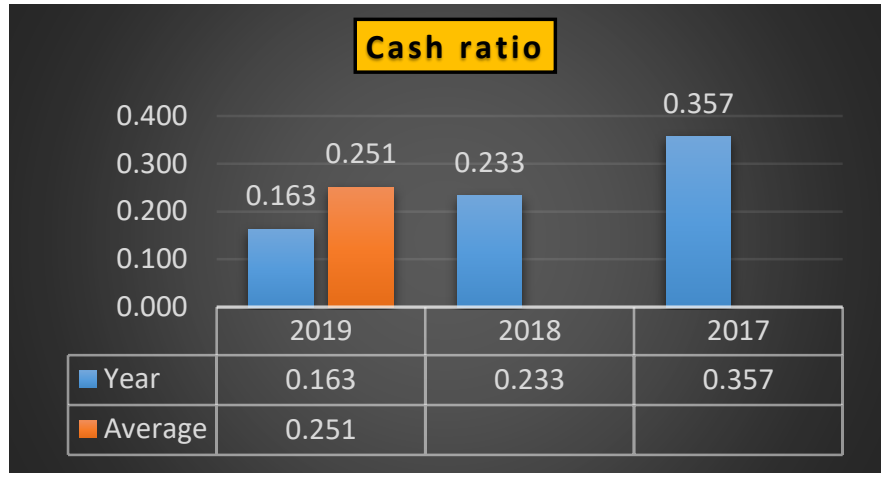

Comments: According to the findings of Cash Ratio shows that, 2017 ware is better performing in the year. Where year average is 0.251 and 2017 is 0.357 . Its measure actual cash and securities easily convertible to cash are used to measure cash ability over year 0.357 .

\section{Profitability Ratio (PR)}

Profitability ratio evaluates the company's ability to generate income against expenses and other cost associated with the generation of income.

Gross margin (GM): Gross margin is calculated as the selling price of an item, less the cost of goods sold. Gross Margin is often used interchangeably with Gross Profit, but the terms are different. Gross Margin=Gross Profit/sales $\{\%\}$

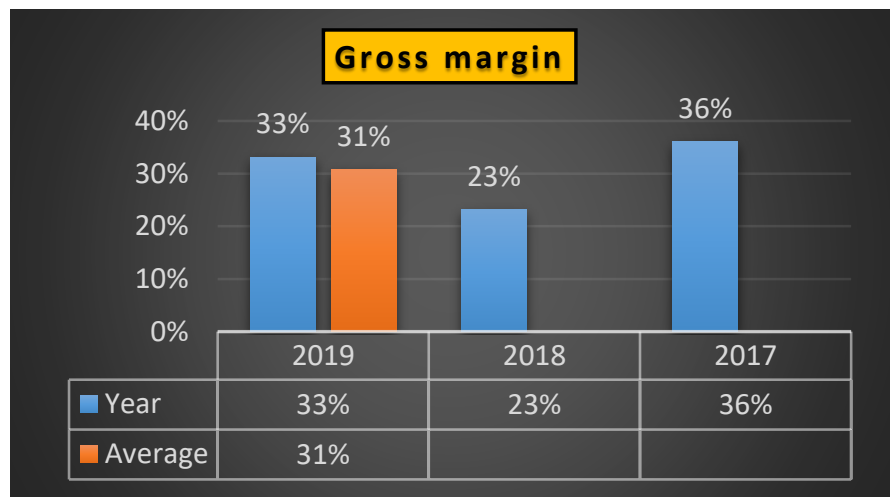

Comments: According to the findings of Gross ratio shows that, 2017 ware is better performing in the year. Where year average is $31 \%$ it shows the relationship between the sales and manufacturing or merchandising cost 2017 has $36 \%$.

Operating profit margin: The ratio of operating income to net sales, usually presented in percent. Operating Profit Margin= Operating Income/Sales $\{\%\}$ 


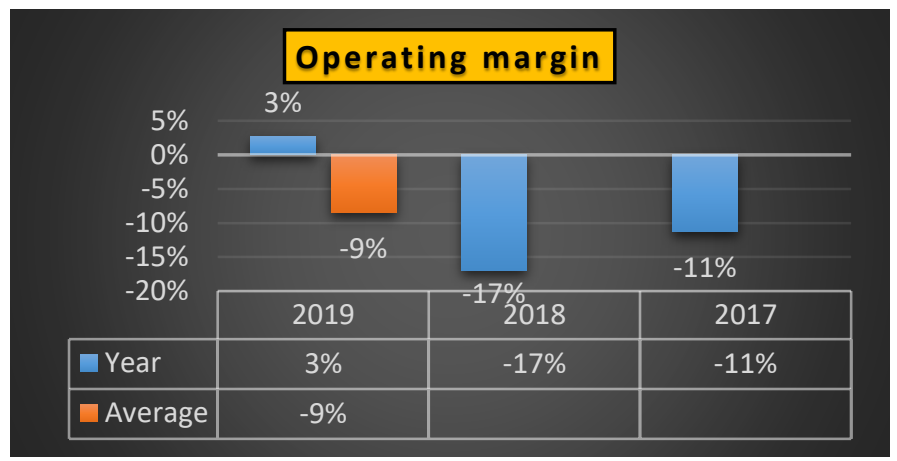

Comments: According to the findings of Operating Margin ratio shows that, 2019 ware is better performing in the year. Average is $-9 \%$ It shows the firms profitability from the operations of its core business excluding the effect of initial startup cost of high finally recovery year 2019 has 3\%.

Pretax margin ratio: This ratio is calculated after financing cost (interest expense) but prior to income taxes. Pretax Margin=EBT/Sales $\{\%\}$.

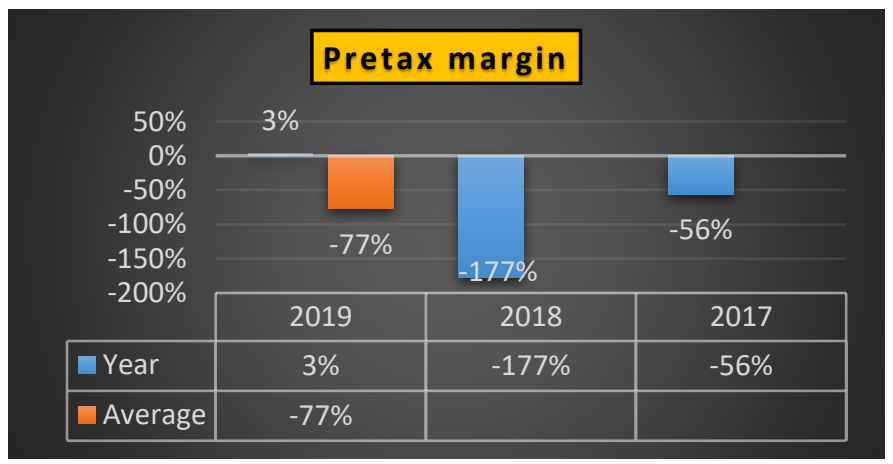

Comments: According to the findings of Pretax Margin ratio shows that, 2019 is better performing in the year. Where year average is $-77 \%$ this ratio is calculated after financing cost but prior to income taxes, excluding the effect of initial startup cost of high finally recovery year 2019 has 3\%.

Margin before interest and tax: EBIT margin is a measure of a company's operating profit as a percentage of its revenue. The acronym stands for earnings before interest, taxes, depreciation, and amortization. Margin Before interest \& Tax=EBIT/Sales $\{\%\}$.

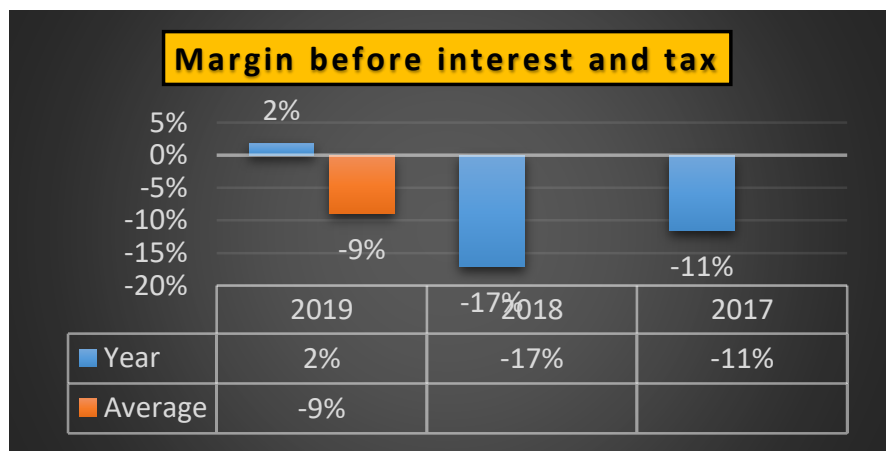


Comments: According to the findings of Margin Before interest \& Tax ratio shows that, 2019 is better performing in the year. Where year average is $-9 \%$. It shows that the firm is independent of both the financing and tax positions, excluding the effect of initial startup cost of high finally recovery year 2019 has $2 \%$.

Net profit margin: Net profit margin is the percentage of revenue remaining after all operating expenses, interest, taxes and preferred stock dividends (but not common stock dividends) have been deducted from a company's total revenue. Net Profit margin=Net income /Sales $\{\%\}$.

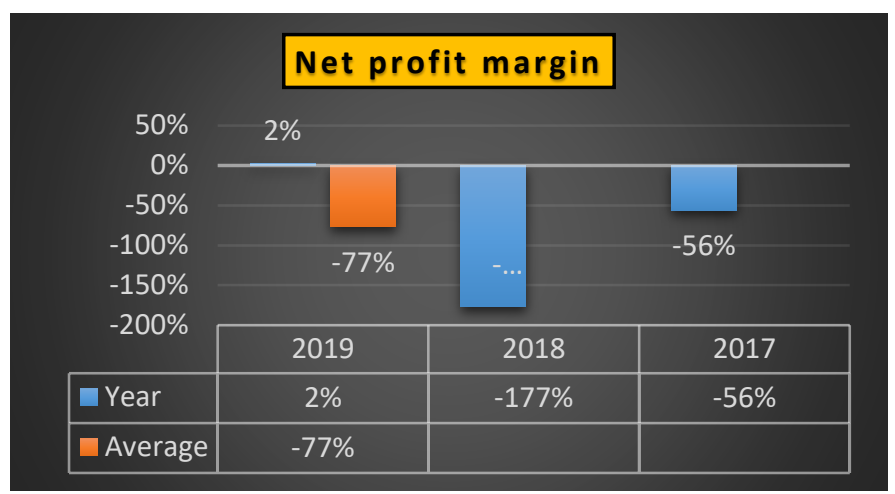

Comments: According to the findings of Net Profit margin ratio shows that, 2019 is better performing in the year. Where year average is $-77 \%$ this ratio measures that percentage of each RMB remaining after all costs and expenses, including interest, taxes, and preferred dividends, have been deducted and excluding's the effect of initial startup cost of high finally recovery year 2019 has $2 \%$.

Return on asset ratio: (ROA) is an indicator of how profitable a company is relative to its total assets. ROA gives a manager, investor, or analyst an idea as to how efficient a company's management is using its assets generate earnings. ROA=Net Income/Average total Assets $\{\%\}$.

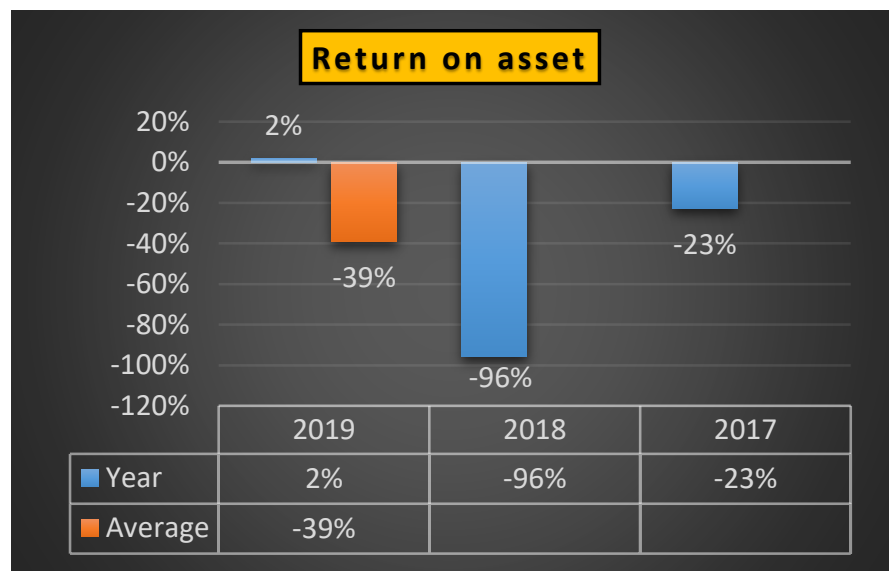

Comments: According to the finding of ROA ratio shows that, 2019 is better performing in the year. Where year average is $-39 \%$ ROA compares income with total assets, excluding's the effect of initial startup cost of high finally recovery year 2019 has $2 \%$. 


\section{Leverage ratio (LR)}

A leverage ratio is any one of several financial measurements that look at how much capital comes in the form of debt (loans) or assesses the ability of a company to meet its financial obligations.

Financial leverage effect: the financial leverage ratios measure the overall debt load of a company and compare it with the assets or equity. (FLE) = Operating income/ Net income.

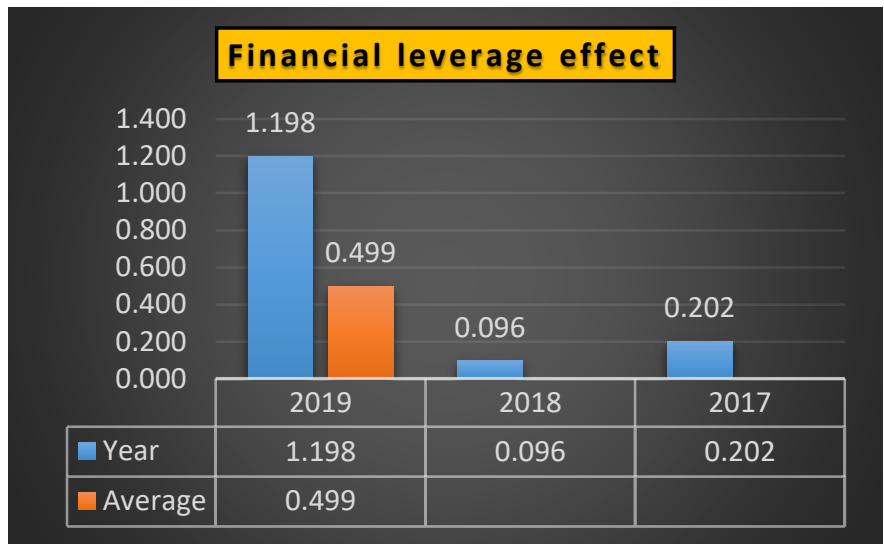

Comments: According to the findings of financial leverage effect shows that, 2019 is better performing in the year. Where year average is 0.499 and 2019 has 1.198.

Operating leverage effect: Operating leverage is a measure of how revenue growth translates into growth in operating income. It is a measure of leverage, and of how risky, or volatile, a company's operating income is. (OLE): Gross profit /operating income.

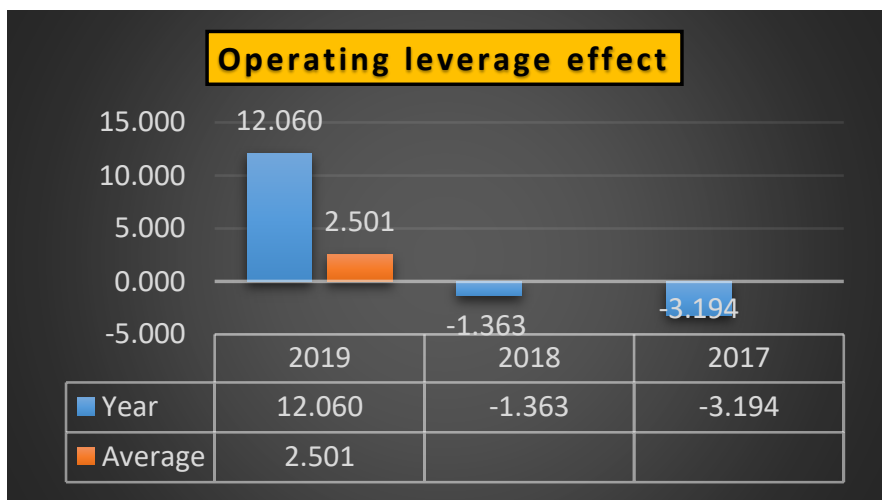

Comments: According to the findings of Operating leverage effect shows that, 2019 is better performing in the year. Where year average is 2.501 and 2019 has 12.060 .

Total leverage effect: It is also called degree of combined leverage, a measure which incorporates the effect of both operating leverage and financial leverage.

Total Leverage Effect (TLE): OLE*FLE

\begin{tabular}{|c|c|c|c|c|}
\hline Year & 2019 & 2018 & 2017 & Average \\
\hline Meituan & 14.453 & -0.131 & -0.644 & 4.560 \\
\hline
\end{tabular}




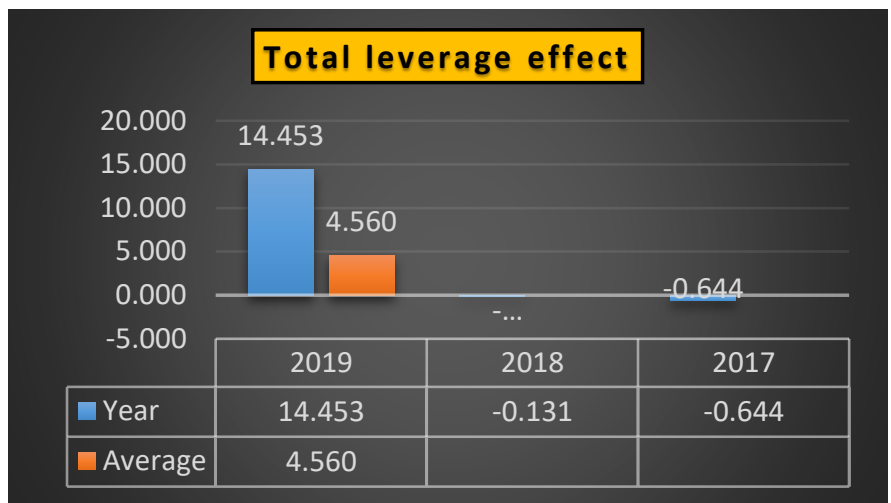

Comments: According to the findings of Total Leverage Effect shows that, 2019 is better performing in the year. Where average is 4.560 and 2019 has 14.453.

\section{Moving average analysis}

The moving average (MA) is a simple technical analysis tool that smooths out price data by creating a constantly updated average price. In This average we taken 100 days' stock price of Meituan in Hong Kong period of time, we test here daily, weekly and monthly advantages to using a moving average. It basically popular to be tailored any time frame, suiting both long-term investors and short-term traders.

Sample period: 100 days (2020, March 04 to 2020, June 12) Meituan Dianping (3690.HK) (Dianping, 2020, June 13).

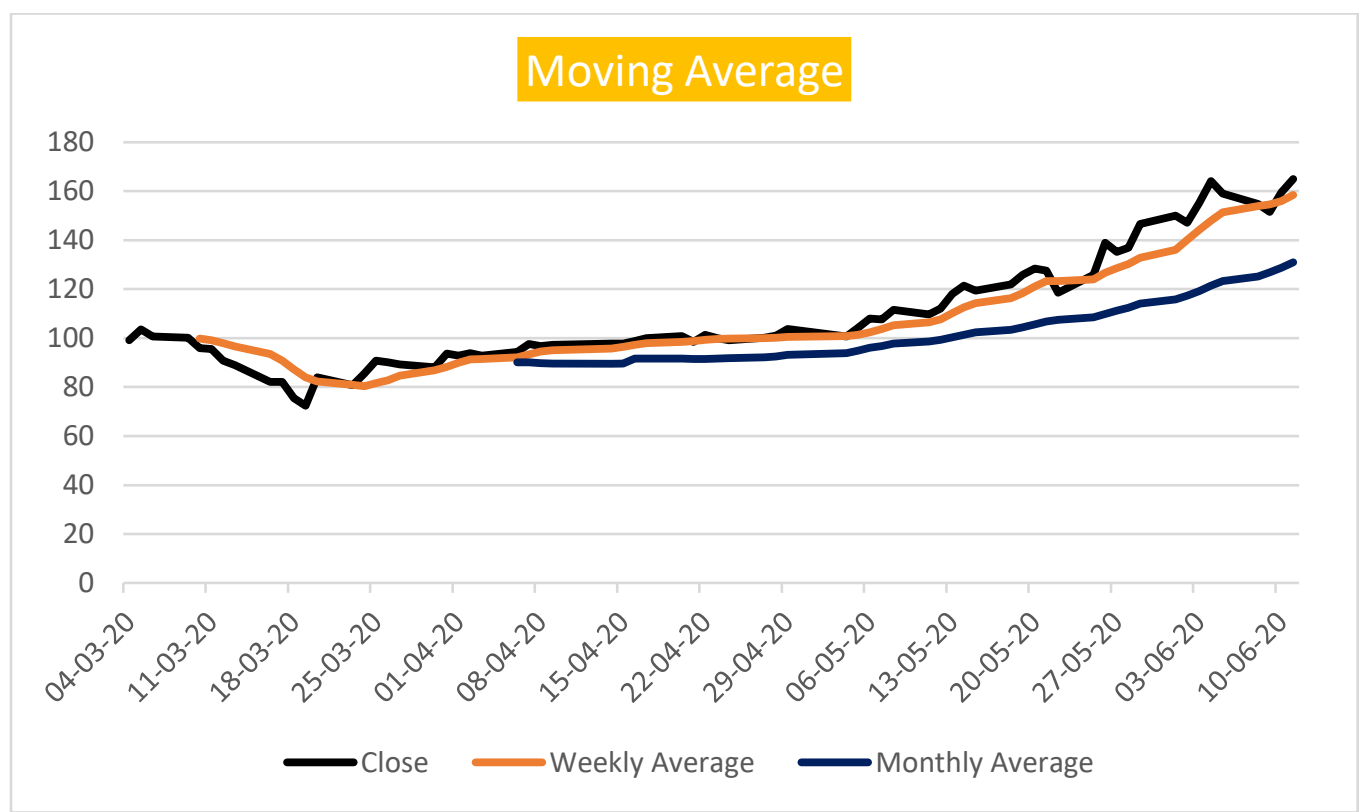

Comments: According to the findings of moving average shows that, the beginning of period daily close was 99.2 then ending of period daily close is 165 . The beginning of weekly average was 99.98 then ending of period is 158.49 . The beginning of monthly average was 90.14 then ending period is 130.98. All indicator is uptrend. 


\section{Price to sales ratio of tech companies}

The price-to-sales $(\mathrm{P} / \mathrm{S})$ ratio is a valuation ratio that compares a company's stock price to its revenues. It is an indicator of the value placed on each RMB of a company's sales or revenues. The $\mathrm{P} / \mathrm{S}$ ratio is an analysis and valuation tool that shows how much investors are willing to pay per RMB of sales for a stock.

Sample collection: 2020, June 13.

\begin{tabular}{|c|c|c|c|c|c|}
\hline Meituan & Tencents & Alibaba & Facebook & Microsoft & Netflix \\
\hline 8.6 & 9.4 & 8.1 & 8.8 & 10.7 & 9.0 \\
\hline
\end{tabular}

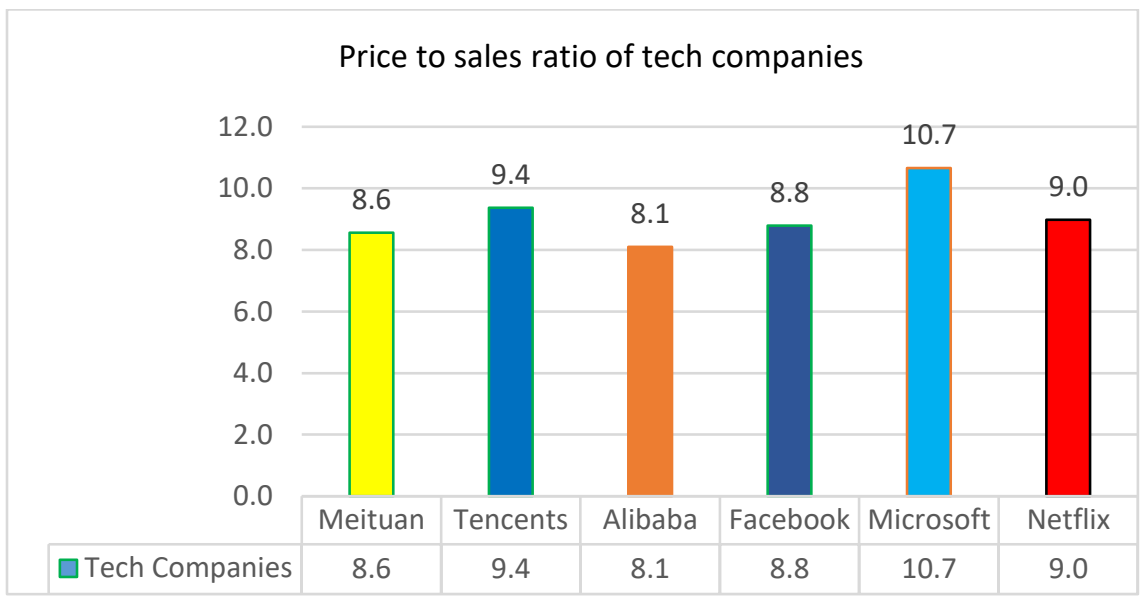

Comments: According to the findings of price to sales ratio shows that, the price to sales ratio is priced similar to other tech companies. That Meituan is waiting, the company will grow strongly by its core market the food delivery business.

\section{FINDINGS OF THE RESEARCH}

\begin{tabular}{|l|l|}
\hline \multicolumn{1}{|c|}{ Name of Ratio } & \multicolumn{1}{c|}{ Interpretation } \\
\hline \multicolumn{2}{|c|}{ Activity Analysis } \\
\hline A-1. Working Capital ratio. & $\begin{array}{l}\text { According to the findings of Working capital turnover } \\
\text { ratio shows that, 2019 Ware better performing in the year. } \\
\text { Where year average is 1.573 times and 2019 is 5.633 times, } \\
\text { That means Working capital amount of operating capital } \\
\text { needed to maintain a given level of sales over year 2.141 } \\
\text { times. }\end{array}$ \\
\hline $\begin{array}{l}\text { A-2. Fixed assets turnover } \\
\text { ratio. }\end{array}$ & $\begin{array}{l}\text { According to the findings of fixed asset turnover ratio } \\
\text { shows that, 2018 Ware is better performing in the year. } \\
\text { Where year average is 23.862 times and 2018 is 16.394 } \\
\text { times, That means Fixed asset turnover ratios measure the } \\
\text { efficiency investment to generate sales a given level of } \\
\text { sales over year 16.394 times. }\end{array}$ \\
\hline
\end{tabular}




\begin{tabular}{|c|c|}
\hline A-3. Total assets turnover. & $\begin{array}{l}\text { According to the findings of total assets turnover ratio } \\
\text { shows that } 2019 \text { are is better performing in the year. Where } \\
\text { year average is } 0.562 \text { times and } 2019 \text { is } 0.739 \text { times, that } \\
\text { means total assets turnover indicates the efficiency with } \\
\text { which the firm uses its assets to generate sales a given level } \\
\text { of sales over year } 0.739 \text { times. }\end{array}$ \\
\hline \multicolumn{2}{|r|}{ Liquidity Analysis } \\
\hline B-1. Current ratio. & $\begin{array}{l}\text { According to the findings of Current Ratio shows that, } \\
2017 \text { ware is better performing in the year where year } \\
\text { average is } 2.399 \text { and } 2017 \text { is } 2.653 \text {, That means the firm's } \\
\text { ability to meet its short term obligation over year } 2.653 \text {. }\end{array}$ \\
\hline B-2. Quick Ratio. & $\begin{array}{l}\text { According to the findings of Quick Ratio shows that, } 2019 \\
\text { Ware is better performing un the year. Where year average } \\
\text { is } 2.391 \text { and } 2019 \text { is } 2.237 \text { It actually measure the immediate } \\
\text { short-term debt paying ability over year } 2.237 \text {. }\end{array}$ \\
\hline B-3. Cash Ratio. & $\begin{array}{l}\text { According to the findings of Cash Ratio shows that, } 2017 \\
\text { ware is better performing in the year. Where year average } \\
\text { is } 0.251 \text { and } 2017 \text { is } 0.357 \text {. Its measure actual cash and } \\
\text { securities easily convertible to cash are used to measure } \\
\text { cash ability over year } 0.357 \text {. }\end{array}$ \\
\hline \multicolumn{2}{|r|}{ Profitability Analysis } \\
\hline C-1. Gross margin ratio. & $\begin{array}{l}\text { According to the findings of Gross ratio shows that, } 2017 \\
\text { ware is better performing in the year. Where year average } \\
\text { is } 31 \% \text { it shows the relationship between the sales and } \\
\text { manufacturing or merchandising cost } 2017 \text { has } 36 \% \text {. }\end{array}$ \\
\hline C-2. Operating profit margin. & $\begin{array}{l}\text { According to the findings of Operating Margin ratio shows } \\
\text { that, } 2019 \text { ware is better performing in the year. Average is } \\
-9 \% \text { It shows the firms profitability from the operations of } \\
\text { its core business excluding the effect of initial startup cost } \\
\text { of high finally recovery year } 2019 \text { has } 3 \% \text {. }\end{array}$ \\
\hline C-3. Pretax margin. & $\begin{array}{l}\text { According to the findings of Pretax Margin ratio shows } \\
\text { that, } 2019 \text { is better performing in the year. Where year } \\
\text { average is }-77 \% \text { this ratio is calculated after financing cost } \\
\text { but prior to income taxes, excluding the effect of initial } \\
\text { startup cost of high finally recovery year } 2019 \text { has 3\%. }\end{array}$ \\
\hline $\begin{array}{l}\text { C-4. Margin before interest } \\
\text { and tax. }\end{array}$ & $\begin{array}{l}\text { According to the findings of Margin Before interest \& Tax } \\
\text { ratio shows that, } 2019 \text { is better performing in the year. } \\
\text { Where year average is }-9 \% \text { It shows that the firm is } \\
\text { independent of both the financing and tax positions, } \\
\text { excluding the effect of initial startup cost of high finally } \\
\text { recovery year } 2019 \text { has } 2 \%\end{array}$ \\
\hline C-5. Net profit margin. & $\begin{array}{l}\text { According to the findings of Net Profit margin ratio shows } \\
\text { that, } 2019 \text { is better performing in the year. Where year }\end{array}$ \\
\hline
\end{tabular}




\begin{tabular}{|c|c|}
\hline & $\begin{array}{l}\text { average is }-77 \% \text { this ratio measures that percentage of each } \\
\text { RMB remaining after all costs and expenses, including } \\
\text { interest, taxes, and preferred dividends, have been } \\
\text { deducted and excluding the effect of initial startup cost of } \\
\text { high finally recovery year } 2019 \text { has } 2 \% \text {. }\end{array}$ \\
\hline C-6. ROA & $\begin{array}{l}\text { According to the finding of ROA ratio shows that, } 2019 \text { is } \\
\text { better performing in the year. Where year average is }-39 \% \\
\text { ROA compares income with total assets, excluding the } \\
\text { effect of initial startup cost of high finally recovery year } \\
2019 \text { has } 2 \% \text {. }\end{array}$ \\
\hline \multicolumn{2}{|c|}{ Operating and Financial Leverage } \\
\hline $\begin{array}{l}\text { D-1. Operating Leverage } \\
\text { effect. }\end{array}$ & $\begin{array}{l}\text { According to the findings of Operating leverage effect } \\
\text { shows that, } 2019 \text { is better performing in the year. Where } \\
\text { year average is } 2.501 \text { and } 2019 \text { has } 3.551 \text {. }\end{array}$ \\
\hline $\begin{array}{l}\text { D-2. Financial leverage Effect } \\
\text { (FLE). }\end{array}$ & $\begin{array}{l}\text { According to the findings of financial leverage effect } \\
\text { shows that, } 2019 \text { is better performing in the year. Where } \\
\text { year average is } 0.499 \text { and } 2019 \text { has } 1.198 \text {. }\end{array}$ \\
\hline D-3. Total Leverage Effect. & $\begin{array}{l}\text { According to the findings of Total Leverage Effect shows } \\
\text { that, } 2019 \text { is better performing in the year. Where average } \\
\text { is } 4.560 \text { and } 2019 \text { has } 14.453 \text {. }\end{array}$ \\
\hline \multicolumn{2}{|r|}{ Moving average analysis } \\
\hline E-1. Moving average. & $\begin{array}{l}\text { According to the findings of moving average shows that, } \\
\text { the beginning of period daily close was } 99.2 \text { then ending of } \\
\text { period daily close is } 165 \text {. The beginning of weekly average } \\
\text { was } 99.98 \text { then ending of period is } 158.49 \text {. The beginning } \\
\text { of monthly average was } 90.14 \text { then ending period is } 130.98 \text {. } \\
\text { All indicator is uptrend. }\end{array}$ \\
\hline \multicolumn{2}{|c|}{ Price to sales ratio of tech companies } \\
\hline F-1. Price to sales ratio. & $\begin{array}{l}\text { According to the findings of price to sales ratio shows that, } \\
\text { the price to sales ratio is priced similar to other tech } \\
\text { companies. That Meituan is waiting, the company will } \\
\text { grow strongly by its core market the food delivery } \\
\text { business. }\end{array}$ \\
\hline
\end{tabular}

\section{CONCLUSION}

The conclusion chapter is directly connected to the purpose. The research will be summarized in order to answer the research questions and fulfill the purpose of the research. Our research is based on seven main research questions. First, I have been analyzed the combination $\mathrm{O} 2 \mathrm{O}$ model with Meituan. The Meituan- $\mathrm{O} 2 \mathrm{O}$ business model based on 6 major frameworks as follows- customer, mobile operators, supper app, offline business entity, payment platform, delivery. Customer can save time for cash less and online services, China's three major mobile operators have lunched their $5 \mathrm{G}$ services with faster and less expensive than 4G, Meituan-Dianping has a supper app is currently 
reached 450 million users, SME's business owner run a business with offline business entity, Amazing payment platforms without service charge, Short time delivery with A.I powered intelligent dispatch system. Second, I have analyzed efficiency measure of working capital turnover, fixed asset turnover, total asset turnover. In year 2019 the company is significant increase in working capital turnover and total asset turnover, then fixed asset turnover 2018 best was very close to 2019. So I have notice the year 2019 is standard position. Third, I have analyzed liquidity measure of current ratio, quick ratio and cash ratio. In year 2017 the company better performer in current ratio as well as cash ratio and year 2019 quick ratio position was better. I have notice that in this measures are very close year to year position. Forth, I have analyzed profitability measures. In year 2019 the company belong standard position, operating margin, pretax margin, margin before interest and tax, net profit margin and return on asset. As well as year 2017 gross margin was best and very close to 2019. I have notice that- the company initial startup cost high for the reason 2017 and 2018 was minus percentage position. Fifth, I have analyzed leverage measures. In year 2019 is far better financial leverage effect, operating leverage effect, total leverage effect than before year. Sixth, I have analyzed moving average (MA). The sample period was 100 days Meituan Dianping (3690.HK). I notice that- daily closing price, weekly average as well as monthly average are shows that uptrend indicator. Seventh, I have analyzed price to sales ratio to other tech companies, the sample collection was 2020, June 13. The Meituan Dianping P/S is 8.6. I notice thatthe price to sales ratio is priced similar to other tech companies. At the final representation, I have view that the year 2019 is the best performance among 2017 and 2018. That Meituan is waiting, the company will grow strongly by its core market the food delivery business.

\section{Recommendation}

- The Meituan working capital turnover 2019 was above two. 1.5 to 2 is interpreted sound solid financial ground. So continuously above 2 is not necessarily considered to be better.

- The Meituan fixed asset turnover is high its means business does this efficiently. In the meantime, balance sheet shows less money for fixed asset- for sustainable growth company should improve fixed assets.

- The Meituan total asset turnover is growing, at present it's below 1. 1-1.5 is interpreted sound solid financial ground. So company need to near future above one.

- The Meituan cash ratio is decreasing, cash ratio standard position is .5 to 1 usually prefect. And 2019 was lowest 0.163 , so company should increase cash ratio.

- The Meituan operating margin ratio is recovery position. In the meantime, recovery position is not sound healthy. So the company should increase operating margin.

- The Meituan pretax margin ratio position is not good. In the last year the company back in positive trade, so the company need to continue and add more pretax margin.

- The Meituan's other profitability ratio also quite bad position. But last year was recovery and achieve positive trend, now the company insure to continue and rapidly increase.

- The Meituan's financial leverage effect is very lower and last financial year sound increase. Too much financial leverage effect can be dangerous. But quite low also not good, so the company insure to increase financial leverage effect. 
- The Meituan's operating leverage effect is not stable, as well as last financial is high operating leverage that is greater the potential danger. And it's a cause small error in forecasting sales. So the company insure stable operating leverage effect.

- The Meituan must to increase the inventory for standardization inventory turnover.

- The Meituan should to increase the receivable for standardization receivable turnover.

\section{ACKNOWLEDGEMENT}

Thanks to Professor Ms. Cheng, Capital Normal University for her continuous supervision on this study.

\section{REFERENCE}

Aiying, M., Yuanyuan, S., \& Jinxia, Y. (2015). The Realization of the O2O Model in Mobile E- Commerce Based on the Technology of the Wechat Platform. Applied Mechanics and Materials Vol. 743 (2015) pp 641-645. https://doi:10.4028/www.scientific.net/AMM.743.641

Dai, H., \& Liu, P. (2019). Workforce planning for O2O delivery systems with crowdsourced drivers. Annals of Operations Research. https://doi.org/10.1007/s10479-019-03135-z

Dianping, M. (2018). About Us Eat Better, Live Better. https://about.meituan.com/en/about

Dianping, M. (2020). https://en.wikipedia.org/wiki/Meituan-Dianping

Ho, H, Y., \& Kitchen, P, J. (2020). Positive crossover loyalty shifts or negative temporal changes? The evolution of shopping mechanism in the $\mathrm{O} 2 \mathrm{O}$ era. European Journal of Marketing Vol. 54 No. 6, 2020 pp. 1383-1405. https://www.emerald.com/insight/0309-0566.htm

Hsich, J, K. (2017). The role of customers in co-creating m-services in the O2O model. Journal of Service Management. https://doi.org/10.1108/JOSM-03-2016-0062

Kosinus, K. [Ying Wu]. (2019, January 16). Meituan Dinping Introduction [video]. YouTube. https://youtu.be/5wxgQVjDviQ

Lu, C., \& Liu, S. (2016). Cultural tourism O2O business model innovation- A case study of Ctrip. Journal of electronic commerce in organization, volume, (14) issue, (2). https://DOI:/10.4018/IECO.2016040102

Moon, Y., \& Armstong, D, J. (2019). Service quality factors affecting customer attitudes in online-to-offline commerce. Information Systems and e-Business Management. https://doi.org/10.1007/s10257-019-00459-y

The investment ABC. (2020, March 05). Meituan Dianping bigger than Alibaba and Tencent stock soon? | stock analysis 2020 [video]. You tube. https://youtu.be/o9eFhueUuSU

Tong, M., \& Zhun, J. (2019). Research of O2O website based consumer purchase decision-making model. Journal of Industrial and Production Engineering. https://doi:10.1080/21681015.2019.1655490

Wan, J., Jiang, Q., \& Zhu, Y. (2016). Research on Core Essential Elements for O2O Business Model with ANP. Wuhan International Conference on e-Business. http://aisel.aisnet.org/whiceb2016/55

Xiao, L., Mi, C., Zhang, Y., \& Ma, J. (2017). Examining Consumers' Behavioral Intention in O2O Commerce from a Relational Perspective: an Exploratory Study. Information Systems Frontiers https://doi.org/10.1007/s10796-017-9815-6

Xu, Q., Wang, W, J., Liu, W., \& Tong, P. (2018). The Influence of Online Subsidies Service on Online-to-Offline Supply Chain. Asia-Pacific Journal of Operational Research Vol. 35, No. 2 (2018) 1840007 (18 pages). https://doi:10.1142/S0217595918400079 
Yu, X., Wang, S., \& Zhang, X. (2019). Ordering Decision and Coordination of a Dual-Channel Supply Chain with Fairness Concerns under an Online-to-Offline Model. Asia-Pacific Journal of Operational Research Vol. 36, No. 2 (2019) $1940004 \quad$ (26 pages). https:/DOI:10.1142/S0217595919400049

$$
--0--
$$

\section{How to Cite this Article}

Hosen, M. S. (2020). O2O Business Model of Meituan in China. Global Disclosure of Economics and Business, 9(1), 49-66. https://doi.org/10.18034/gdeb.v9i1.508 